\title{
A novel mechanism of phenotypic heterogeneity in Creutzfeldt-Jakob disease
}

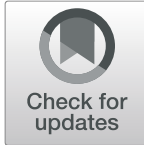

Satish K. Nemani ${ }^{1}$, Xiangzhu Xiao ${ }^{2}$, Ignazio Cali ${ }^{1,3}$, Laura Cracco ${ }^{1}$, Gianfranco Puoti ${ }^{4}$, Massimiliano Nigro ${ }^{5}$, Jody Lavrich ${ }^{1}$, Anuradha Bharara Singh ${ }^{6}$, Brian S. Appleby ${ }^{1,3,7,8}$, Valerie L. Sim ${ }^{9}$, Silvio Notari ${ }^{1}$, Witold K. Surewicz ${ }^{2}$ and Pierluigi Gambetti ${ }^{*}$ (D)

\begin{abstract}
One of remarkable features of sporadic Creutzfeldt-Jakob disease (sCJD) is the great phenotypic variability. Understanding the molecular basis of this variability has important implications for the development of therapeutic approaches. It is well established that, in many cases, phenotypic heterogeneity of sCJD is under control of two determinants: the genotype at the methionine $(\mathrm{M}) /$ valine $(\mathrm{V})$ polymorphic codon 129 of the human prion protein gene and the type, 1 or 2, of the pathogenic and disease-related form of the prion protein, $\operatorname{Pr} P^{\mathrm{D}}$. However, this scenario fails to explain the existence of distinct heterozygous SCJDMV2 subtypes, where heterogeneity occurs without any variation of the 129 allotype and $\operatorname{PrP}^{\mathrm{D}}$ type. One of these subtypes, denoted SCJDMV2C, associated with $\mathrm{PrP}^{\mathrm{D}}$ type 2, is characterized by widespread spongiform degeneration of the cerebral cortex (C). The second variant, denoted SCJDMV2K, features prominent deposition of PrPD amyloid forming kuru type $(K)$ plaques. Here we used a mass spectrometry based approach to test the hypothesis that phenotypic variability within the SCJDMV2 subtype is at least partly determined by the abundance of $129 \mathrm{M}$ and $129 \mathrm{~V}$ polymorphic forms of proteinase K-resistant $\operatorname{PrP}^{\mathrm{D}}$ (resPrPD). Consistent with this hypothesis, our data demonstrated a strong correlation of the MV2C and MV2K phenotypes with the relative populations of protease-resistant forms of the pathogenic prion proteins, resPrP $P^{\mathrm{D}}-129 \mathrm{M}$ and resPrP $\mathrm{P}_{\text {- }}$ $129 \mathrm{~V}$, where resPrPD-129 M dominated in the sCJDMV2C variant and resPrP ${ }^{\mathrm{D}}-129 \mathrm{~V}$ in the SCJDMV2K variant. This finding suggests an important, previously unrecognized mechanism for phenotypic determination in human prion diseases.
\end{abstract}

Keywords: Prion protein allotype, $129 \mathrm{M}$ and $129 \mathrm{~V}$ proportion, $129 \mathrm{M} / \mathrm{V}$ polymorphism, Epitope mapping, Mass spectrometry

\section{Introduction}

The variability of the clinical presentation in CreutzfeldtJakob disease (CJD) has been known for many years and has led to the identification of several clinical variants [5]. In subsequent years, we showed that the phenotypic heterogeneity of the sporadic form of CJD (sCJD) is largely driven by the pairing of two sets of major determinants of disease

\footnotetext{
* Correspondence: pxg13@case.edu

'Department of Pathology, Case Western Reserve University, School of Medicine, Cleveland, OH 44106, USA

Full list of author information is available at the end of the article
}

phenotype: the genotype- MM, MV, $\mathrm{V}-$ at the methionine $(\mathrm{M})$ / valine (V) polymorphic codon 129 of the human prion protein $(\mathrm{PrP})$ gene and the type, 1 or 2 , of the pathogenic, disease-related form of the prion protein $\left(\operatorname{PrP}^{\mathrm{D}}\right)[12,24,25$, $27,29]$. $\operatorname{PrP}^{\mathrm{D}}$ type 1 and 2 , which were initially distinguished by the electrophoretic mobilities as species with $21 \mathrm{kDa}$ (type 1) and $19 \mathrm{kDa}$ (type 2) proteinase-resistant cores, $\operatorname{resPr}^{\mathrm{D}}$, of the unglycosylated forms, were shown to represent two fundamental prion strains associated with sCJD [3, 29, 31]. This concept led to a new classification of sCJD that theoretically included six phenotypes or subtypes: MM, MV and VV, each 
of which could be associated with $\operatorname{PrP}^{\mathrm{D}}$ type 1 or 2 . Indeed, as expected, sCJD patients with the 129 MM genotype coupled with $\operatorname{PrP}^{\mathrm{D}}$ type 1 , commonly identified as sCJDMM1 (hereafter MM1), as well as SCJDVV2, VV1 and MV2 were associated with distinct disease phenotypes (Table 1). Some of these phenotypes mimicked the clinical variants originally proposed, while some were novel. However, detailed analyses revealed two apparent inconsistencies. First, MM1 and MV1 were shown to share histopathological phenotype and $\operatorname{PrP}^{\mathrm{D}}$ electrophoretic profile, prompting their grouping into one sCJD subtype, namely MM (MV) 1 [12, 27]. Second, MM2 was associated with two quite distinct phenotypes: one with SCJD-like features including severe spongiform degeneration (SD) of the cerebral cortex, named sCJDMM2 (or MM2C for cortical), and the other, very rare, characterized by insomnia and severe thalamic atrophy that is commonly referred to as sporadic fatal insomnia (sFI or MM2T for thalamic) [8]. Specific variations of $\operatorname{PrP}^{\mathrm{D}}$ as well as distinct transmission characteristics indicate that MM2 and sFI are associated with distinct prion strains $[3,9,19,26]$.

Recently, the issue of phenotypic heterogeneity within the MV2 subtype has also emerged [23, 28] (Table 1). The MV2 subtype was shown to comprise two basic histopathological phenotypes (or histotypes) as well as two electrophoretic profiles of $\operatorname{respr}^{\mathrm{D}}$ : a variant that was indistinguishable from the MM2 subtype (named sCJDMV2C) and a second phenotype that, although generally mimicking SCJDVV2, differed from the latter with regard to the prominent presence of kuru plaques (MV2K) as well as the presence of a small additional resPrP ${ }^{\mathrm{D}}$ component in the otherwise type 2 resPrP $\mathrm{P}^{\mathrm{D}}$ profile. The coexistence in the same case of the two histotypes in various proportions (MV2K-C) was also observed.

In 2016, Moore et al. carried out a mass spectrometric study to determine the relative amount of $\operatorname{resPrP}^{\mathrm{D}}-129$ $\mathrm{M}$ and $-129 \mathrm{~V}$ in $\operatorname{PrP}^{\mathrm{D}}$ enriched preparations extracted from MV1, MV2C and MV2K cases as well as cases with mixed histotypes, such as MV2K-C and MV1-2C [20]. Based on the finding that the ratios of $\operatorname{resPrP} P^{\mathrm{D}}-129 \mathrm{M}$ and $-129 \mathrm{~V}$ allotypes were highly variable, the authors concluded that, in MV2 and MV1 cases, normal or cellular $\operatorname{PrP}\left(\operatorname{PrP}^{\mathrm{C}}\right)-129 \mathrm{M}$ and $-129 \mathrm{~V}$ had "similar tendency to misfold" into $\operatorname{PrP}^{\mathrm{D}}$ regardless of the MV histotype, and that "factors other than the $\operatorname{PrP}^{\mathrm{Sc}}$ allotype abundance must influence the clinical progression and the phenotype of heterozygous cases of CJD".

Here, we have re-examined the issue of resPrP $\mathrm{P}^{\mathrm{D}}-129 \mathrm{M}$ and $-129 \mathrm{~V}$ relative abundance in the SCJDMV case subset using mass spectrometry. Given the variability, sometimes subtle, of the phenotype in these cases, we extensively analyzed the histotype and $\operatorname{PrP}^{\mathrm{D}}$ characteristics to select $\mathrm{MV} 2 \mathrm{C}$ and $\mathrm{MV} 2 \mathrm{~K}$ cases associated with only one phenotype (called "pure"), along with MV2K-C mixed cases, where the two histotypes coexisted in welldefined proportions. In all MV2 cases examined, we consistently observed a positive correlation between the relative dosage of $\operatorname{resPr}^{\mathrm{D}}-129 \mathrm{M}$ and $-129 \mathrm{~V}$ allotypes and the MV2C and MV2K histotypes. However, surprisingly, in the MV1 variant, $\operatorname{resPrP}^{\mathrm{D}}-129 \mathrm{M}$ and $-129 \mathrm{~V}$ were equally represented.

\section{Materials and methods}

\section{Brain tissues}

All frozen and fixed brain tissues were obtained from the National Prion Disease Pathology Surveillance Center (NPDPSC) at Case Western Reserve University (CWRU) in Cleveland, OH. A cohort of 23 subjects was selected that, according to common SCJD subtype classifications, comprised 21 cases harboring exclusively one histotype, and 2 cases with mixtures of two co-existing histotypes [1,27]. The $21 \mathrm{sCJD}$ "pure" cases cohort included: 4 MM1; 3 MV1; 4 MM2; 4 MV2C; 3 MV2K; 3 VV2. Three cases of pure MV2C, MV2K, and MV1 each and two cases in which the histotype was mixed were

Table 1 Synopsis of molecular classification and phenotypes of sCJD subtypes and variants

\begin{tabular}{|c|c|c|}
\hline $\begin{array}{l}\text { SCJD subtype } \\
\text { Prevalence }(\%)\end{array}$ & Histopathological phenotype & $\begin{array}{l}\text { WB } \\
\text { resPrpD Profile }\end{array}$ \\
\hline $\mathrm{MV} 2 \mathrm{~K} ; \sim 8$ & SD pseudo-laminar in CC (Fig. 1a-d); kuru pl. in Cbl. IHC: fine punctate in CC; Cbl (Fig. 1a-d) & $\begin{array}{l}\text { Type } 2(19 \mathrm{kDa})+\text { Type } \sim 1 \\
(20 \mathrm{kDa})\end{array}$ \\
\hline $\mathrm{MV} 2 \mathrm{C}_{;} \sim 2$ & SD: large confluent vacuoles mostly in CC. IHC: co-distributing with SD (Fig. 1e-h). & Type 2 (19 kDa) \\
\hline$M V 1 ; 5$ & $\begin{array}{l}\text { SD with fine vacuoles predominantly in CC; } I \mathrm{HC} \text { : fine punctate pattern in SD regions; in Cbl } \\
\text { "brushstroke" pattern (Fig. 1s-u) }\end{array}$ & Type 1 (21 kDa) \\
\hline W2; 15 & SD like MV2K in CC; no kuru plaques but plaque-like aggregates in Cbl (Not shown) & Type 2 (19 kDa) \\
\hline MM2; 4 & As MV2C (Fig. 1i-l) & $\begin{array}{l}\text { Similar but not identical to } \\
\text { MV2C }\end{array}$ \\
\hline MM1; 64 & As MV1 (Fig. 1v-x) & As MV1 \\
\hline
\end{tabular}

a Subtype terminology: $\mathrm{M}$ (methionine) and $\mathrm{V}$ (valine) refer to the genotype at PrP codon 129; 1 and 2 refer to PrP ${ }^{\mathrm{D}}$ types 1 and 2, which along with the 129 genotype are major determinants of the disease phenotype; the $\mathrm{C}$ in MV2C refers to the severe involvement of the cerebral cortex in this condition as in MM2; $\mathrm{K}$ in MV2K refers to the presence of kuru plaques. Abbreviations: CC cerebral cortex, SD spongiform degeneration, IHC PrP immunohistochemistry. Figure 1 panels illustrate the features of SD and IHC patterns. The VV1 subtype (2\% prevalence) has been omitted 
used for mass spectrometry analyses. In one of the mixed cases, the MV2K and MV2C histotypes co-existed in equal ratio (50:50); in the other one, the cerebral cortex showed pure MV2C histotype while the mixed MV2K $+C$ histotype with a 90:10 ratio was observed in the cerebellar cortex.

\section{Reagents and antibodies}

Tris-buffered saline (TBS), Tris/glycine buffer, Tris/glycine/SDS buffer, Tween 20, $\beta$-mercaptoethanol, Dithiothreitol (DTT), Laemmli sample buffer, Non-fat dry milk, 15\% Criterion Tris- $\mathrm{HCl}$ polyacrylamide gels were procured from Bio-Rad Laboratories (Hercules, CA, USA). Benzonase, Polyvinylidene difluoride (PVDF) (Immobilion-P and Immobilon-FL) were purchased from Millipore Sigma (Burlington, MA, USA). $1 \mathrm{M}$ Tris- $\mathrm{HCl}$, $\mathrm{N}$-Lauroylsarcosine sodium salt solution, 3- Indole acetic acid, $8 \mathrm{M}$ Guanidine-hydrochloride, (GdnHCl), Calcium chloride, Phenylmethylsulfonyl fluoride (PMSF), Dulbecco's Phosphate Buffered Saline (D-PBS), Proteinase K, Iodoacetamide (IAA) and Ammonium bicarbonate were obtained from Sigma-Aldrich. NuPAGE 4-12\% Bis-Tris gradient gels, NuPAGE MES SDS running buffer (20X), Acetonitrile, Silver Staining kit, Ethanol, Formic Acid, Methanol, Pierce ECL 2 Western Blotting Substrate, Odyssey Blocking Buffer and Trypsin from Thermo Fisher Scientific Inc. (Waltham, MA, USA). The following antibodies were used: 3F4 (to human PrP residues 106-110) [15], 12B2 (to human PrP residues 89-93) [18, 32], Tohoku-2, polyclonal antibody (to residues 97-103) [17] and SAF32 (to human prion octapeptide repeat region 59-89) [11], Alkaline phosphatase-conjugated goat anti mouse or anti rabbit (Promega, Madison, WI, US), Horseradish peroxidase (HRP)- conjugated sheep antimouse or donkey anti-rabbit IgG Ab sheep anti-mouse IgG (GE Healthcare Life Sciences, Chicago, IL, USA) and Infrared Dye (IRDye) $800 \mathrm{CW}$ goat anti-mouse IgG (LI-COR Biosciences, Lincoln, NE, USA).

\section{Molecular genetics}

DNA was isolated from frozen brain tissues and genotyping of PRNP coding region was performed as previously described [25].

\section{Histopathology}

Histopathology and immunohistochemistry were performed essentially as described previously $[5,6]$.

\section{PK-resistant $\operatorname{PrP}^{\mathrm{D}}$ analysis}

Brain homogenates $(\mathrm{BH})(10 \% w / v)$ were prepared as previously described [22]. Brain homogenate was centrifuged at $1000 \mathrm{x}$ g for $10 \mathrm{~min}$ and supernatant (S1) was collected. S1 were treated with $70 \mathrm{U} / \mathrm{ml}$ proteinase $\mathrm{K}$ (PK) and incubated at $37^{\circ} \mathrm{C}$ for $1 \mathrm{~h}$. Protease digestion was stopped by adding $4 \mathrm{mM}$ PMSF. Samples were mixed with equal volumes of $2 \mathrm{X}$ sample buffer (6\% SDS, 8\% 2-mercaptoethanol, 20\% glycerol, 4 mM EDTA, 125 $\mathrm{mM}$ Tris $\mathrm{HCl} \mathrm{pH} \mathrm{6.8),} \mathrm{boiled} \mathrm{for} 10 \mathrm{~min}$ and incubated with 8-fold pre-chilled methanol overnight at $-20^{\circ} \mathrm{C}$. The following day, the samples were centrifuged at 18 , $200 \mathrm{x} \mathrm{g}$ for $30 \mathrm{~min}$, pellets were resuspended in $1 \mathrm{X}$ sample buffer by sonication and subjected to immunoblotting.

Protein samples (brain tissue equivalent $0.1-3 \mathrm{mg}$ of wet tissue) were separated in 4-12\% NuPAGE Bis-Tris gradient gels and blotted into Immobilon-FL membranes for $40 \mathrm{~min}$ at $30 \mathrm{~V}$, blocked with $5 \%$ nonfat dry milk in TBS-T (1× TBS with $0.1 \%$ Tween 20 ) and probed with the indicated antibodies. Immunoblots were visualized by ImageQuant LAS 4000 or by Odyssey infrared imaging system (LICOR Biosciences) as described by the manufacturer.

\section{Conformational stability immunoassay (CSI)}

CSI was performed according to previous protocols $[4,30,35]$ with slight modifications. Aliquots of $\mathrm{BH}$ $(10 \% w / v)$ prepared in LB100 $(\mathrm{pH} 8.0)$ were centrifuged at $1000 \times \mathrm{g}$ for $10 \mathrm{~min}$ at $4{ }^{\circ} \mathrm{C}$ and the $\mathrm{S} 1$ fraction were collected. Fifty $\mu$ l aliquot of S1 was diluted with an equal volume of $\mathrm{GdnHCl}$ to obtain final $\mathrm{GdnHCl}$ concentrations ranging from 0 to $3.5 \mathrm{M}$ and samples were incubated for $1.5 \mathrm{~h}$ at $22^{\circ} \mathrm{C}$. Gdn $\mathrm{HCl}$ was subsequently removed by incubating each sample with an excess of 8-fold pre-chilled methanol overnight at $-20^{\circ} \mathrm{C}$, followed by centrifugation at 18 , $200 \times \mathrm{g}$ for $30 \mathrm{~min}$. Pellets were resuspended in $50 \mu \mathrm{l}$ LB100 (pH 8.0) by sonication. Each aliquot was digested with $10 \mathrm{U} / \mathrm{ml} \mathrm{PK}$ for $1 \mathrm{~h}$ at $37^{\circ} \mathrm{C}$ and reaction was terminated by addition of $4 \mathrm{mM}$ PMSF. Samples were denatured and loaded onto $15 \%$ precast Tris- $\mathrm{HCl}$ gels. PrP amounts at different $\mathrm{GdnHCl}$ concentrations were measured by Odyssey application software V3.0. The conformational stability curves (i.e., fraction of remaining $\operatorname{PrP}^{\mathrm{D}}$ as a function of $\mathrm{GdnHCl}$ concentration) for unglycosylated $\mathrm{PrP}^{\mathrm{D}}$ were fitted to a sigmoidal equation using GraphPad Prism. The mean $[\mathrm{GdnHCl}]_{1 / 2}$ values \pm standard error of the mean (SEM) were calculated and compared between histotype case groups.

\section{Proteinase $\mathrm{K}$ titration assay}

The proteinase $\mathrm{K}(\mathrm{PK})$ titration assay was performed as described previously [7]. Briefly, $30 \mu \mathrm{l}$ of S1 was treated with different concentrations of PK $(0.62,1.25,2.5,5,10$, 20, 40, 80, $160 \mathrm{U} / \mathrm{ml}$ ) for $1 \mathrm{~h}$ at $37^{\circ} \mathrm{C}$. Additionally, S1 was incubated with $320 \mathrm{U} / \mathrm{ml}$ of PK for $12 \mathrm{~h}$ at $37^{\circ} \mathrm{C}$. The PK digestion was terminated with $4 \mathrm{mM}$ PMSF; equal aliquots of $2 \mathrm{X}$ sample buffer were added and 
samples were boiled for $10 \mathrm{~min}$ and subjected to immunoblotting with 3F4. The PK points from 5 to $320 \mathrm{U} /$ $\mathrm{ml}$ of the unglycosylated resPrP $\mathrm{P}^{\mathrm{D}}$ fragment from sCJD variants were best fitted using one phase decay and $\mathrm{PK}_{1 / 2}$ index values \pm SEM were determined and compared between subtypes.

\section{Purification of resPrP}

Purification of resPrP ${ }^{\mathrm{D}}$ was performed as previously reported [10] following extraction from the cerebral cortex (CC) of sCJDMV1, MM2, MV2C, MV2K, VV2 and and MV2K-C cases. In a mixed case containing the sCJDMV2C histotype in the cerebral cortex and the sCJDMV2K in the cerebellum, $\operatorname{resPrP}^{\mathrm{D}}$ was purified also from the cerebellar cortex.

\section{Silver staining}

Purity of resPrP ${ }^{\mathrm{D}}$ corresponding to different sCJD subtypes was analyzed by gel electrophoresis with silver staining detection according to manufacturer instructions (Thermo Fisher Scientific Inc., Waltham, MA, USA).

\section{In-solution digestion of purified resPrP ${ }^{D}$}

In-solution trypsin digestion was performed according to the previously method [14] with some modifications. Briefly, purified resPrP ${ }^{\mathrm{D}}$ samples were dissociated by incubation with $8 \mathrm{M} \mathrm{GdnHCl}$ for $10 \mathrm{~min}$; this was followed by reduction with DTT and alkylation with IAA step. After centrifugation, the supernatant was collected and incubated overnight at $-20^{\circ} \mathrm{C}$ with nine volumes of methanol to precipitate the protein. The precipitates were pelleted by centrifugation at $21,130 \mathrm{x}$ g for $30 \mathrm{~min}$ at $4{ }^{\circ} \mathrm{C}$ and then resuspended in $100 \mathrm{mM}$ ammonium bicarbonate. Trypsin (MS grade, Thermo Scientific) was dissolved according to the manufacturer's instructions and added to the protein solution at the enzyme to resPrP ${ }^{\mathrm{D}}$ weight ratio of $1: 10$. The mixture was incubated overnight at $37^{\circ} \mathrm{C}$ with shaking, and the reaction was terminated by adding formic acid to a final concentration of $5 \%(\mathrm{vol} / \mathrm{vol})$. Samples were concentrated to a volume of $\sim 20 \mu \mathrm{l}$ and stored at $-80^{\circ} \mathrm{C}$ until analysis by Nano LC-MS.

\section{Nano LC-MS/MS}

Nanospray LC-MS-MS analysis was performed using an LTQ Orbitrap XL mass spectrometer equipped with nanoelectrospray source (Thermo Scientific, San Jose, CA). Trypsin-digested samples were loaded onto a C-18 trap column (to remove salts) and separated on a C-18 column (Acclaim PepMap, Thermo Scientific, CA) connected to an emitter. Separation was performed using a Dionex UltiMate 3000 system (Thermo Scientific, San Jose, CA) and a gradient of acetonitrile in water containing $0.1 \%$ formic acid. The flow rate was $300 \mathrm{nl} / \mathrm{min}$. The mass spectrometer was externally calibrated using a Pierce LTQ ESI positive ion calibration solution (Thermo Scientific, catalog number 88322). MS-MS data in full scan experiments were acquired in the $\mathrm{m} / \mathrm{z} 300$ 1800 range at a resolution of 30,000 (FWHM at $\mathrm{m} / \mathrm{z}$ 400). The following source settings were used: spray voltage $=4.2 \mathrm{kV}$; capillary temperature $=200{ }^{\circ} \mathrm{C}$. Datadependent $\mathrm{MS}^{\mathrm{n}}(n=2)$ were acquired at ITMS using collision induced dissociation (CID); the top 14 intense ions were subjected for further fragmentation. Calculation of elemental formulae was performed on the monoisotopic peak of each ion cluster using Xcalibur software v2.2 with a mass tolerance of 3 to $5 \mathrm{ppm}$. MS/MS raw files were searched using MASCOT Deamon engine against the database containing sequence of human prion protein $129 \mathrm{M} / \mathrm{V}$. Trypsin/P search parameters for Mascot peptide identification included one missed tryptic cleavage, fixed carbamidomethylation (+ $57 \mathrm{Da}$, Cys), and variable oxidation (+16 Da, Met). Mass tolerances of 2.0 and 1.0 Da were used for parent and monoisotopic fragment ions, respectively. The resulting files generated by MASCOT were used for peptide identification with the constraints that only MASCOT ion scores greater than 10 were considered. The percentage of 129 $\mathrm{M}$ and $129 \mathrm{~V} \operatorname{PrP}$ in $\operatorname{resPrP}^{\mathrm{D}}$ samples was calculated by the spectral counting method [2].

\section{Calibration curves for allotypic ratio determination}

To obtain a calibration curve, recombinant full-length human $129 \mathrm{M}$ and $129 \mathrm{~V}$ PrP were purified as described previously [21,33] and the concentration of each protein was determined by absorbance at $280 \mathrm{~nm}$ using the extinction coefficient of $57,995 \mathrm{M}^{-1} \mathrm{~cm}^{-1}$. Both proteins were combined at the $129 \mathrm{M} \operatorname{PrP}$ to $129 \mathrm{~V}$ PrP molar ratios of $0: 100,25: 75,50: 50,75: 25$, and 100:0. After insolution trypsin digestion, the samples were analyzed by mass spectrometry to determine the relative ratio of the $129 \mathrm{M}$ and $129 \mathrm{~V}$ polymorphs as described above. A similar calibration curve was also obtained using purified human resPrP ${ }^{\mathrm{D}}$ from SCJDMM2 and sCJDVV2 subtypes by combining the proteins at the same the molar ratios. For this purpose, resPrP ${ }^{\mathrm{D}}$ from sCJDMM2 and sCJDVV2 subtypes were quantified from Western blots by densitometry using the Odyssey application software V3.0. Recombinant PrP was used as a standard for this Western blot-based quantification.

\section{Statistical analysis}

Statistical significance was assessed with the one-way analysis of variance (ANOVA) followed by multiple pairwise comparisons with the Tukey test supported by GraphPad Prism 8.0. 


\section{Results}

\section{Histopathology and immunohistochemistry}

Detailed histopathological evaluation, including immunohistochemical and semiquantitative assessments of the individual lesions and staining patterns, led to the selection of three representative cases of pure MV2C, MV2K and MV1 histotypes (Fig. 1, panels a-n and s-x, and Table 1). We also selected two cases of MV2K-C where the MV2C and MV2K histotypes were mixed in different proportions. One of these cases was characterized by approximately equal proportion of the two histotypes throughout the brain. In the other case, the cerebral cortex harbored only the MV2C histotype, whereas the cerebellar cortex contained both histotypes, with a MV2K and MV2C ratio of 9:1 (Fig. 1, panels n-r).

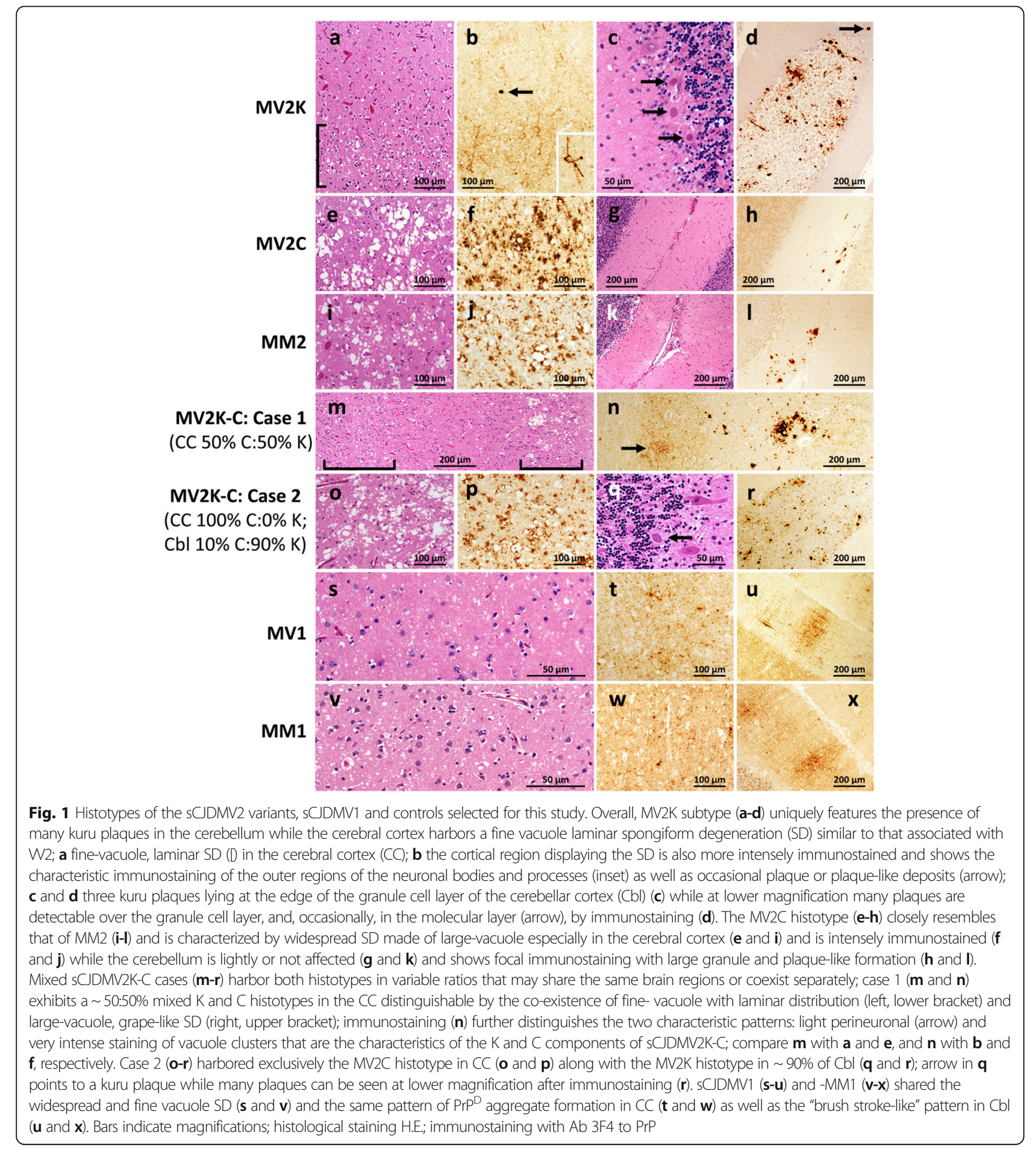




\section{Immunoblotting and epitope mapping}

Consistent with the histopathological findings, the immunoblot analysis of the selected cases and appropriate controls revealed different electrophoretic profiles of resPrP ${ }^{\mathrm{D}}$ associated with distinct $\mathrm{MV}$ histotypes (Fig. 2, Table 1). When probed with $\mathrm{Ab} 3 \mathrm{~F} 4$ (resPrP $\mathrm{P}^{\mathrm{D}}$ type nonspecific), resPrP $\mathrm{P}^{\mathrm{D}}$ from $\mathrm{MV} 2 \mathrm{~K}$ and $\mathrm{MV} 2 \mathrm{~K}-\mathrm{C}$ cases uniquely showed an additional $20 \mathrm{kDa}$ band, which represents the unglycosylated isoform and has an electrophoretic mobility that is intermediate between $21 \mathrm{kDa}$ and $19 \mathrm{kDa}$ of $\operatorname{resPrP}^{\mathrm{D}}$ type 1 and 2 , respectively. The type 1-specific Ab 12B2 strongly reacted not only with resPrP ${ }^{\mathrm{D}}$ type 1 of $\mathrm{MM} 1$ and MV1 preparations, but also with the above mentioned $20 \mathrm{kDa}$ component. As expected, 12B2 did not recognize the type 2-specific 19 $\mathrm{kDa}$ band. Remarkably, when probed with $\mathrm{Ab} 12 \mathrm{~B} 2$ the $20 \mathrm{kDa}$ component appeared to co-migrate with resPrP ${ }^{\mathrm{D}}$ type 1 to 21 rather than $20 \mathrm{kDa}$ as it does with $\mathrm{Ab} 3 \mathrm{~F} 4$. This finding indicates that the $20 \mathrm{kDa}$ component comprises at least two resPrP $\mathrm{P}^{\mathrm{D}}$ populations: a small subpopulation with a more $\mathrm{N}$-terminal end and $21 \mathrm{kDa}$ electrophoretic mobility that is exclusively recognized by the more $\mathrm{N}$-terminus $\mathrm{Ab} 12 \mathrm{~B} 2$; by contrast, the general $\mathrm{Ab} 3 \mathrm{~F} 4$ likely reacts with both populations but the larger $20 \mathrm{kDa}$ population dictates the position of the electrophoretic band. Predictably, all type $2 \operatorname{resPrP}^{\mathrm{D}}$ subtypes (MM2, MV2C and VV2) were negative when probed with Ab 12B2 (Fig. 2b). Probing with Ab Tohoku-2 (type 2-specific) confirmed first that the "20-21" kDa resPrP ${ }^{\mathrm{D}}$ fragment has resPrP $\mathrm{P}^{\mathrm{D}} \mathrm{N}$-terminus consistent with type 1 since it did not react with Tohoku-2; second, it demonstrated that the $19 \mathrm{kDa}$ component coexisting with the $20-21 \mathrm{kDa}$ resPrP ${ }^{\mathrm{D}}$ component has type $2 \mathrm{~N}$-terminus characteristics (Fig. 2c). Ab SAF32 (epitope residues 5788) reacted with MM1 and MV1, but not (or very weakly) with $\mathrm{MV} 2 \mathrm{~K}$ resPrP $\mathrm{P}^{\mathrm{D}}$, confirming the more $\mathrm{C}$ terminal PK cleavage of the bulk of the $20 \mathrm{kDa}$ fragment (Fig. 2d). Overall, the MV2C profile was very similar, though not identical, to that of MM2, showing a slightly lower mobility of the three glycoform bands, which is clearly more pronounced for the diglycosylated band, when probed with Ab 3F4 and To-2 (Fig. 2).

\section{Conformational stability and PK titration assays}

The conformational stability index (the concentration of $\mathrm{GdnHCl}$ corresponding to midpoint $\operatorname{PrP}^{\mathrm{D}}$ denaturation, $[\mathrm{GdnHCl}]_{1 / 2}$ ) overall correlated with the histotype and resPrP ${ }^{\mathrm{D}}$ electrophoretic profiles (Fig. 3a, Additional File 1: Table S1 and Additional File 3: Figure S1a). Analysis of all major SCJD subtypes uncovered a significant difference between [GdnHC] $]_{1 / 2}$ for MV2K and all other subtypes, especially the MV2C subtype ( $1.1 \mathrm{M}$ vs. $1.6 \mathrm{M})$. Remarkably, the $20 \mathrm{kDa}$ species, when analyzed individually, was less stable than the canonical $\operatorname{resPrP}^{\mathrm{D}}$

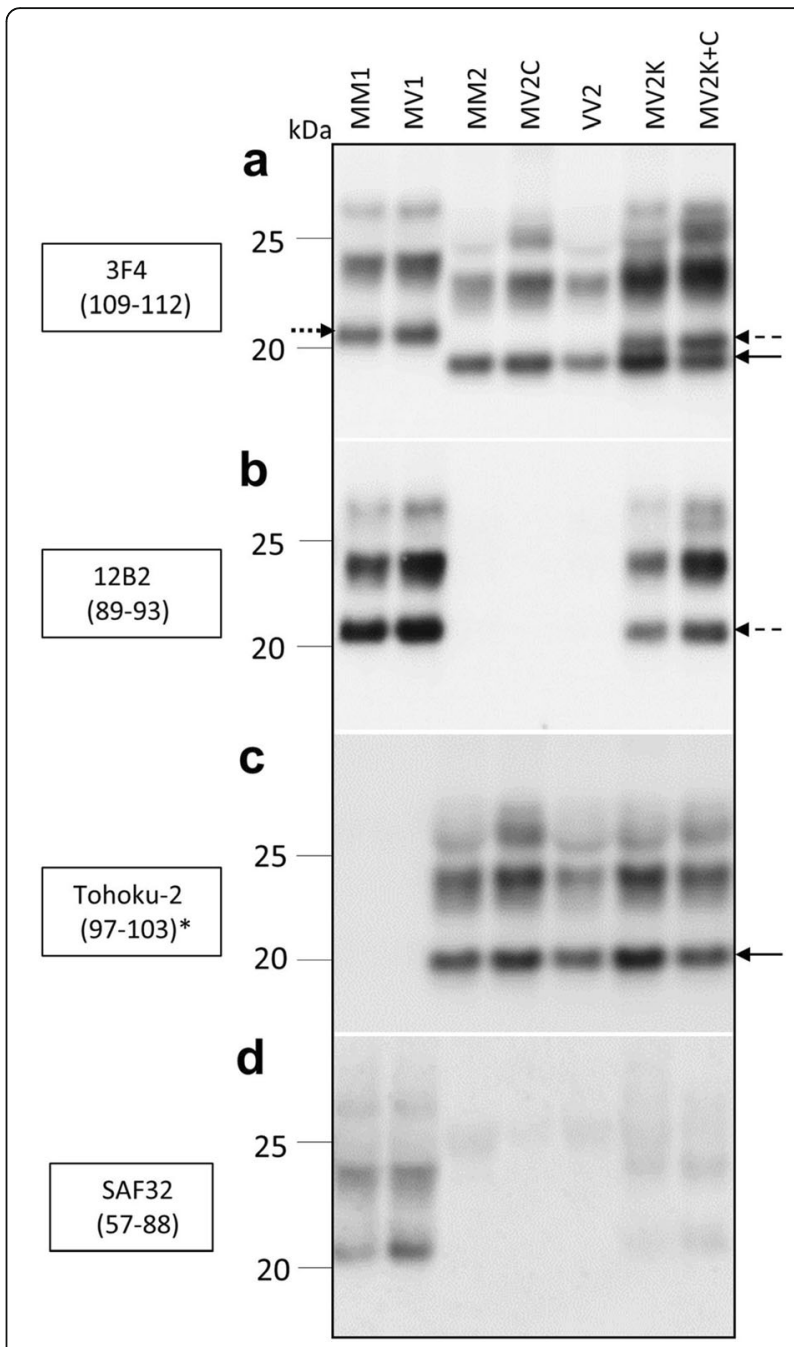

Fig. 2 Immunoblot and $\mathrm{N}$-terminus epitope mapping of resPrP $\mathrm{P}^{\mathrm{D}}$ from SCJDMV2 variants, SCJDMV1 and controls. a both resPrP ${ }^{D}$ types 1 and 2 (arrows) from all MV variants reacted with the type-nonspecific Ab 3F4. The three resPrPD major glycoform are present in all preparations. The unglycosylated components shows the $\sim 21 \mathrm{kDa}$ mobility of resPrP ${ }^{\mathrm{D}}$ type 1 in -MM1 and -MV1 (dotted arrow), and the $19 \mathrm{kDa}$ mobility of resPrPD type 2 (solid arrow) in all other preparations. Both "pure" sCJDMV2K and the mixed variant MV2K-C (50:50\%) exclusively display the $20 \mathrm{kDa}$ band (dashed arrow) along with the $19 \mathrm{kDa}$ type 2 component (solid arrow). b type 1-specific $\mathrm{Ab} 12 \mathrm{~B} 2$, besides resPrPD type 1 of MM1 and MV1, also demonstrated all three glycoforms of the $20 \mathrm{kDa}$ component in SCJDMV2K and MV2K-C (dashed arrow) confirming the type 1-like N-terminus immunoreactivity of the $20 \mathrm{kDa}$ as well as of its other two glycoform components; note that unlike with $3 \mathrm{~F} 4$, when probing with $\mathrm{Ab} 12 \mathrm{~B} 2$ the " 20 " $\mathrm{kDa}$ band (dashed arrow) aligns with the unglycosylated isoform of MM1 and MV1 at $21 \mathrm{kDa}$. c Ab Tohoku-2, type 2-specific, reacted only with all resPrPD type 2 as indicated by the $19 \mathrm{kDa}$ unglycosylated isoform (solid arrow). d SAF32 (to slightly more Nterminal epitopes than 12B2) recognizes resPrPD type 1 of $\mathrm{MM} 1$ and MV1 but not (or very weakly) resPrPD associated with MV2K and MV2KC. All tissue samples were obtained from the frontal cortex. ${ }^{*}$ Residue 97 (or another C-terminally closely adjacent $\mathrm{N}$-terminus) is required for Tohoku-2 to immunoreact [17] 


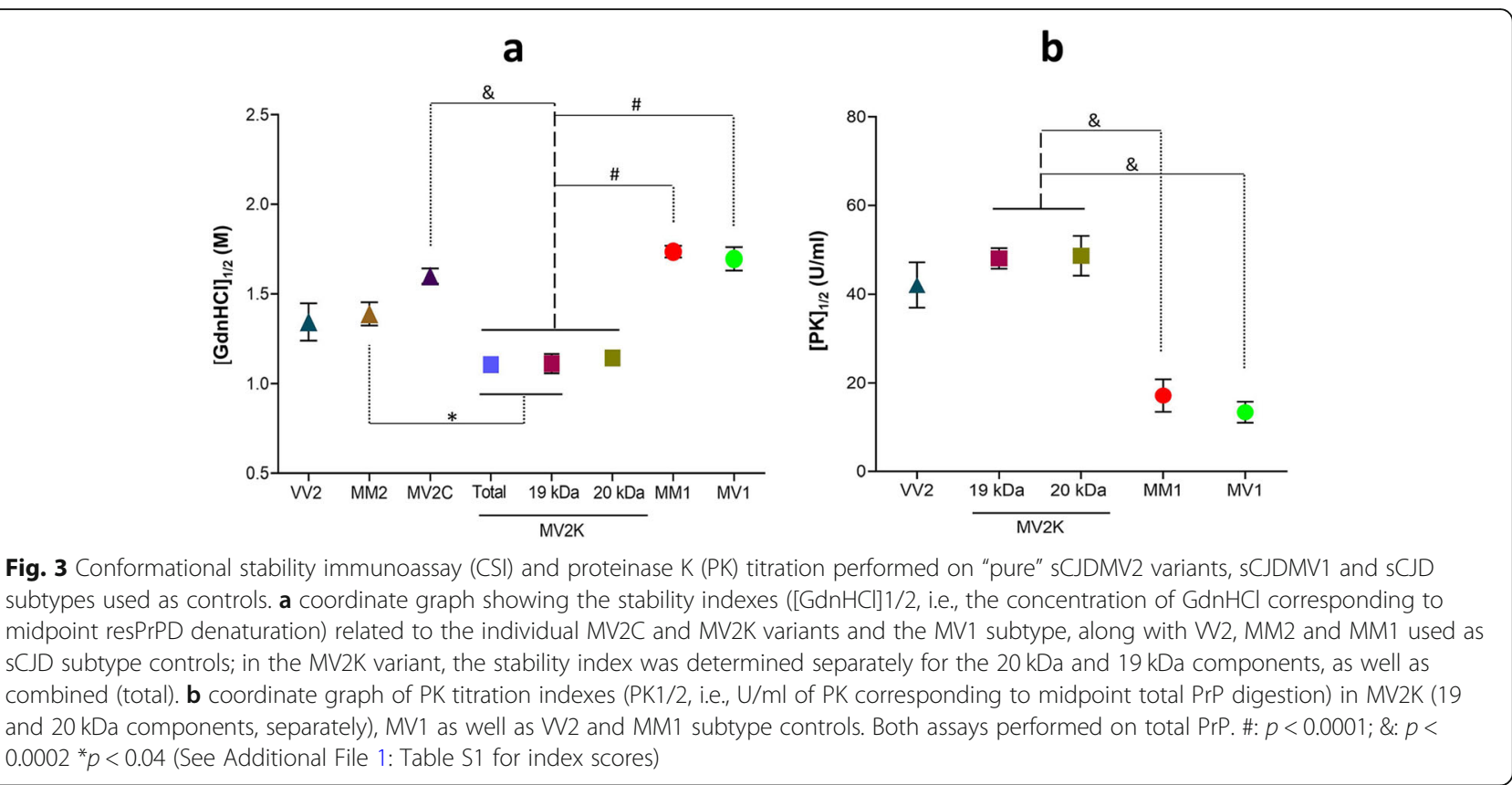

associated with the MM1 and MV1 subtypes. As expected, no significant difference was observed between the stability of $\operatorname{PrP}^{\mathrm{D}}$ associated with $\mathrm{MM} 2$ and $\mathrm{MV} 2 \mathrm{C}$ subtypes, as well as between $\operatorname{PrP}^{\mathrm{D}}$ associated with MM1 and MV1 subtypes, which share the histotype and electrophoretic profile (Fig. 3a, Additional File 1: Table S1 and Additional File 3: Figure S1a). Essentially similar results were obtained with the PK titration assay: again, the MV2K 20 and $19 \mathrm{kDa}$ components and VV2 shared the $\mathrm{PK}_{1 / 2}$ index, which significantly differed from those of MM1, MV1 and VV1 (Fig. 3b, Additional File 1: Table S1 and Additional File 3: Figure S1b).

\section{Determination of relative populations of resPrP $\mathrm{P}^{\mathrm{D}}-129 \mathrm{M}$ and $-129 \mathrm{~V}$ by mass spectrometry Calibration of mass spectrometry-based assay}

As first step in assessing the capability of our assay to accurately determine the relative population of the two resPrP ${ }^{\mathrm{D}}$ allotypes in clinical samples, we performed experiments with the recombinant human $\operatorname{PrP}$ (rhuPrP) (Additional File 4: Figure S2a). Two polymorphic forms of the protein, rhuPrP-129M and $-129 \mathrm{~V}$ (concentration of which can be accurately determined by absorption spectroscopy), were combined in five different proportions and analyzed by Nano LC-MS as described in the Methods section. The relative quantities of rhuPrP-129 M and $-129 \mathrm{~V}$ as determined by mass spectrometry correlated almost perfectly with those measured by absorption spectroscopy $\left(R^{2}=0.98\right)$ (Additional File 4: Figure S2a). A similar calibration was performed using resPrP $\mathrm{P}^{\mathrm{D}}-129 \mathrm{M}$ and $-129 \mathrm{~V}$ purified from MM2 and VV2 cases (Additional File 4: Figure S2b) in which PrP concentration was determined by densitometry of Western blots. Peptide mapping identified multiple $\operatorname{PrP} 111-136$ and $\operatorname{PrP} 111-$ 148 fragments (Additional File 2: Table S2), which were used to determine the proportions of $\operatorname{res} \operatorname{PrP}^{\mathrm{D}}-129 \mathrm{M}$ and $-129 \mathrm{~V}$ in five different mixtures of these samples. The relative quantities of resPrP $\mathrm{P}^{\mathrm{D}}-129 \mathrm{M}$ and $-129 \mathrm{~V}$ correlated reasonably well with those determined from Western blots (Additional File 4: Figure S2b). A somewhat lower correlation $\left(R^{2}=0.91\right)$ in this case is likely due to the lower accuracy of densitometric analysis of Western blots compared to protein concentration determination by absorption spectroscopy. Altogether, these calibration experiments validate our mass spectrometry-based approach as an accurate tool to determine proportions of resPrP $\mathrm{P}^{\mathrm{D}}$ $129 \mathrm{M}$ and $-129 \mathrm{~V}$ in complex clinical samples.

\section{Mass spectrometric determination of resPrP $P^{D}-129 \mathrm{M}$ and - 129 V proportions in MV2 subtypes}

We next determined the abundance resPrP $\mathrm{P}^{\mathrm{D}}-129 \mathrm{M}$ and $-129 \mathrm{~V}$ in three pure cases of sCJD MV2C and MV2K (Fig. 4 and Additional File 5: Figure S3). Remarkably, $\mathrm{MV} 2 \mathrm{C}$, the histotype of which is virtually indistinguishable from that of $\mathrm{MM} 2 \mathrm{C}$, showed a large predominance of the $129 \mathrm{M}$ allotype, with $\operatorname{resPr} \mathrm{P}^{\mathrm{D}}-129 \mathrm{M}$ accounting for $83 \pm 7 \%$ of total resPrP $\mathrm{P}^{\mathrm{D}}$, a difference between populations of $\operatorname{resPr}^{\mathrm{D}}-129 \mathrm{M}$ and $-129 \mathrm{~V}$ statistically highly significant $(p<0.0001)$. By contrast, a diametrically different ratio of the $129 \mathrm{M}$ and $129 \mathrm{~V}$ allotypes was observed in sCJD MV2K cases, where $\operatorname{resPrP}^{\mathrm{D}}-129 \mathrm{M}$ accounted for only $23 \pm 7 \%$ of total $\operatorname{res} \operatorname{PrP}^{\mathrm{D}}(p<0.0002$ for the difference between populations of $\operatorname{resPrP}^{\mathrm{D}}-129 \mathrm{M}$ and $-129 \mathrm{~V}$ ) (Fig. 4 and Additional File 5: Figure S3). 


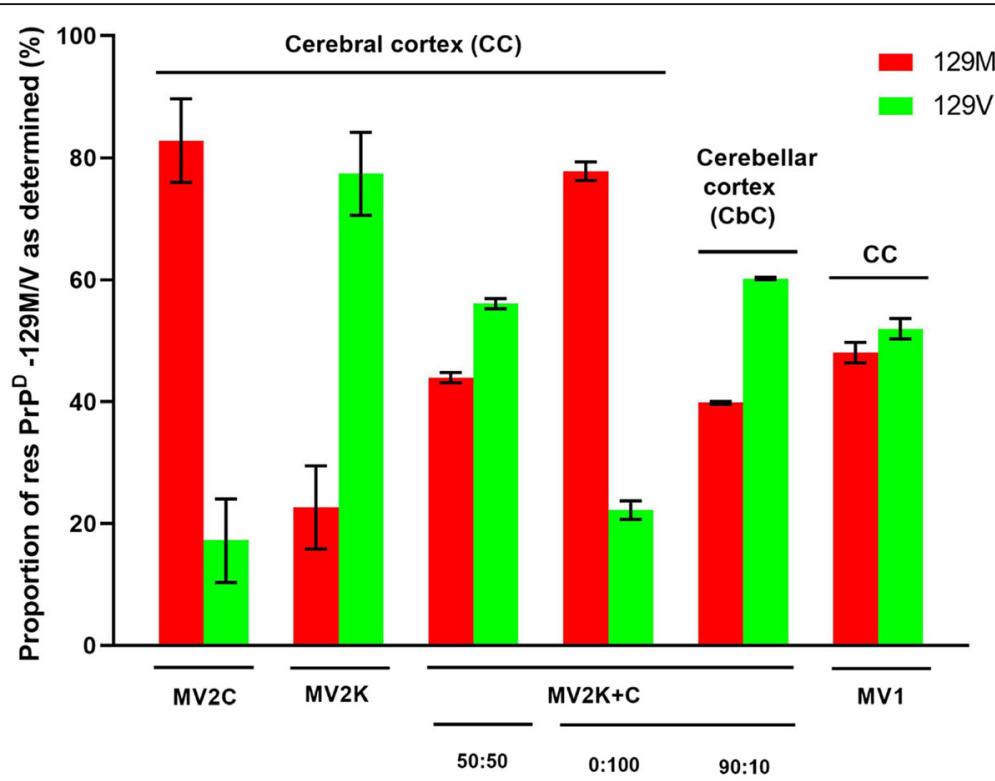

Fig. 4 Relative abundance of $129 \mathrm{M}$ and $129 \mathrm{~V}$ resPrPD purified from distinct variants of sCJDMV. Relative proportions of both allotypic proteins in each case were determined by mass spectrometry using the spectral counting method. For the histotypically pure MV1, MV2C and MV2K variants data \pm SEM are averages of three determinations for each of the nine total cases. For the mixed cases MV2K-C ( 50:50) and MV2K-C 0:100 K:C in the cerebral and $\sim 90: 10 \mathrm{~K}: \mathrm{C}$ in the cerebellar cortices, data are averages of three MS determination for each case. The fractions (\%) of resPrPD -129 M in each MV2 variant and the MV1 subtype are: $83 \pm 7 \%$ for MV2C, $23 \pm 7 \%$ for MV2K, and $48 \pm 2 \%$ for MV1. In pure MV2C and MV2K cases, the relative amounts of resPrPD $-129 \mathrm{M}$ and $129 \mathrm{~V}$ are significantly different $(p<0.0001$ and 0.0002 , respectively) whereas in MV1 the difference is not significant. In the two MV2K-C mixed cases, the resPrPD-129 M proportion is 44\% for the CC 50:50 first case; 78 and $40 \%$, respectively, for the CC $0: 100$ and $C b C \sim 90: 10$. As determined by one way ANOVA, $p$ values for differences in relative populations of the two resPrPD allotypic forms in distinct SCJD variants and subtypes are: MV2C vs. MV2K, $p<0.0001$; MV1 vs. MV2C $p<0.009$

We also used the mass spectrometric method to assess the proportion of the resPrP ${ }^{\mathrm{D}}-129 \mathrm{M}$ and $-129 \mathrm{~V}$ in two distinct mixed MV2K-C sCJD cases. The first of these cases, in which the two histotypes were about evenly distributed throughout the cerebrum, was characterized by a comparable representation of $\operatorname{res} \operatorname{PrP}^{\mathrm{D}}-129 \mathrm{M}$ and $-129 \mathrm{~V}$ (44 and 56\%, respectively) (Fig. 4 and Additional File 5: Figure S3). The second variant harbored mixed, though anatomically segregated histotypes, with the MV2C histotype localized almost exclusively to the cerebrum and the MV2K histotype predominating in the cerebellum (Fig. 4 and Additional File 5: Figure S3). Consistent with distinct regional distribution of the two haplotypes, $\operatorname{resPr}^{\mathrm{D}}-129$ $\mathrm{M}$ and $-129 \mathrm{~V}$ in the cerebral cortex of this mixed variant accounted for $\sim 78$ and $22 \%$ of total resPrP ${ }^{\mathrm{D}}$, respectively, whereas the proportion of $\operatorname{resPrP}^{\mathrm{D}}-129 \mathrm{M}$ and $-129 \mathrm{~V}$ in the cerebellum was $\sim 40$ and $60 \%$, respectively (Fig. 4 and Additional File 5: Figure S3).

A similar analysis was also undertaken for the sCJDMV1 subtype that shares the MM1 histotype (Fig. 1 , panels $\mathrm{s}-\mathrm{x}$ and Table 1 ). In this case, $\operatorname{resPrP}^{\mathrm{D}}-129 \mathrm{M}$ and $-129 \mathrm{~V}$ were represented in approximately equal proportions, accounting for $\sim 48 \pm 2$ and $52 \pm 2 \%$, respectively of total resPrP ${ }^{\mathrm{D}}$ (Fig. 4 and Additional File 5: Figure S3).
Finally, the identification of residue 129 and the Nterminus in the 20 and $19 \mathrm{kDa}$ components of MV2K was also attempted. The single successful experiment aimed at determining the ratio of $\operatorname{res} \operatorname{PrP}^{\mathrm{D}}-129 \mathrm{M}$ and $-129 \mathrm{~V}$ selectively in the $20 \mathrm{kDa}$ fragment revealed the exclusive presence of methionine at position 129. Furthermore, three independent experiments identified G82, G86 and S97 N-termini, the first two of which are likely to be $\mathrm{N}$-termini of the $20 \mathrm{kDa}$ fragment, and the third of the $19 \mathrm{kDa}$ component.

\section{Discussion}

It is increasingly clear that successful treatment of prion diseases may need to be tailored to individual prion strain [13]. This notion underscores the need for the detailed understanding of the mechanisms of strain emergence and selection that lead to the heterogeneity of human prion diseases. This mechanistic insight will also likely have implications for development of therapeutic strategies in other neurodegenerative diseases that are characterized by prion-like propagation and structural polymorphism of misfolded protein aggregates.

Previous studies showed that both the $\operatorname{PrP}^{\mathrm{D}}$ type 1 and 2 selection as well as phenotypic heterogeneity of $\mathrm{sCJD}$ are largely under the control of the 129 allotype (for 
review see $[12,34])$. However, this scenario does not explain the phenotypic heterogeneity of the SCJDMV2 subtype, where the heterogeneity occurs without any variation of the 129 allotype and $\operatorname{PrP}^{\mathrm{D}}$ type (Table 1 ).

To bridge this gap, here we have performed detailed characterization of different subtypes of sCJDMV cases, and for each of these cases we have used a massspectrometry based approach to determine the relative proportion of resPrP $\mathrm{P}^{\mathrm{D}}-129 \mathrm{M}$ and $-129 \mathrm{~V}$. This analysis revealed a novel, versatile mechanism by which residue 129 polymorphism of resPrP ${ }^{\mathrm{D}}$ determines phenotypic heterogeneity, resulting in multiple variants within the MV2 subtype of sCJD. In particular, our data show that the occurrence of two variants, referred to as MV2C and $\mathrm{MV} 2 \mathrm{~K}$, either with pure or mixed phenotypes, is directly related to the relative abundance of $\operatorname{resPrP}^{\mathrm{D}}-129 \mathrm{M}$ and $129 \mathrm{~V}$. The pure MV2C phenotype is characterized by large predominance of resPrP $\mathrm{P}^{\mathrm{D}}-129 \mathrm{M}$. By contrast, in the pure MV2K phenotype, the predominant form of resPrP ${ }^{\mathrm{D}}$ contains Val at position 129 , with resPrP $\mathrm{P}^{\mathrm{D}}-129 \mathrm{M}$ accounting only for $\sim 23 \%$ of total resPrP $\mathrm{P}^{\mathrm{D}}$. Furthermore, consistent with the notion that the nature of amino acid at position $129(\mathrm{M}$ or $\mathrm{V})$ is a major determinant of disease phenotype in heterozygous cases of SCJD, we found that, in MV2K-C mixed phenotypes, the relative abundance of resPrP-129M and $-129 \mathrm{~V}$ correlates with the representation of the corresponding histotypes in these mixed cases. Of note, the second MV2K-C case shows that histotyperelated quite different allotypic proportions of resPrP $\mathrm{P}^{\mathrm{D}}$ may occur in two separate regions of the same brain (in this case, cerebral and cerebellar cortices), suggesting that local mechanisms play a role in determining this topographic heterogeneity.

Different proportions of resPrP $\mathrm{P}^{\mathrm{D}}$ corresponding to two allotypes as determined in this study likely result from the preferential templated conversion of the normal form of $\operatorname{PrP}\left(\operatorname{PrP}^{C}\right)$ that matches the allotype of the dominant resPrP ${ }^{\mathrm{D}}$. One cannot completely rule out the possibility that the observed different proportions of resPrP-129 $\mathrm{M}$ and $-129 \mathrm{~V}$ in $\mathrm{MV} 2 \mathrm{C}$ and MV2K cases result from differences in the resistances to PK digestion. However, this possibility is highly unlikely given that the MV2C and MV2K variants share PK titration profiles and conformational stabilities or both with the VV2 and MM2 subtypes, which, being 129 homozygous, are associated with $\operatorname{PrP}^{\mathrm{D}}$ isoforms allotypically homogeneous.

Remarkably, even in the histotypically pure cases, neither $\operatorname{res} \operatorname{PrP}^{\mathrm{D}}-129 \mathrm{M}$ nor the $\operatorname{res} \operatorname{PrP}^{\mathrm{D}}-129 \mathrm{~V}$ allotype accounted for $100 \%$ of total $\operatorname{resPrP} \mathrm{P}^{\mathrm{D}}$, with the minor allotype always observed. Even though one cannot absolutely rule out the possibility that this apparent coexistence of both resPrP ${ }^{\mathrm{D}}$ allotypes in pure phenotypes is due to a systematic error of our mass spectrometry-based measurements, this is rather unlikely. Thus, the presence of a small population $(\sim 20 \%)$ of $\operatorname{resPrP}^{\mathrm{D}}-129 \mathrm{~V}$ in MV2C cases appears to be an intrinsic property of this phenotype. This is very intriguing given the similarity of the MV2C and MM2 subtypes, both with regard to the histotype and resPrP ${ }^{\mathrm{D}}$ conformational stability index. In this variant, $\operatorname{PrP}^{\mathrm{C}}-129 \mathrm{~V}$ might be converted into $\operatorname{PrP}^{\mathrm{D}}$ that adopts the $\operatorname{PrP}^{\mathrm{D}}$ MM2-like conformation and contributes to the MM2-like histotype. Alternatively, this minor resPrP $\mathrm{P}^{\mathrm{D}}$ component might remain "silent" with its histotype undetectable $[4,7]$.

The coexistence of $\operatorname{resPrP}^{\mathrm{D}}-129 \mathrm{~V}$ and $-129 \mathrm{M}$ (77: 23 ratio) in the MV2K variant raises even more challenging questions, especially given the presence in this variant of two resPrP $\mathrm{P}^{\mathrm{D}}$ electrophoretic components of $19 \mathrm{kDa}$ and $20 \mathrm{kDa}$. Data from our and other laboratories allowed for detailed characterization of these two components. With regard to the allotype, our sole successful attempt at sequencing the $20 \mathrm{kDa}$ resPrP $\mathrm{P}^{\mathrm{D}}$ component indicated the presence of the $\mathrm{M}$ residue at position 129. However, transmission of the MV2K variant to knock-in $129 \mathrm{MM}, \mathrm{MV}$ and VV transgenic mice demonstrated that the $20 \mathrm{kDa}$ component can be replicated only in the presence of at least one $129 \mathrm{M}$ allele [16] . Altogether, these data identify the $20 \mathrm{kDa}$ fragment as the sole component populating $\operatorname{resPr} \mathrm{P}^{\mathrm{D}}-129 \mathrm{M}$ in the $\mathrm{MV} 2 \mathrm{~K}$ subtype. Furthermore, further bioassays in $129 \mathrm{M}$ allotypic mouse lines have shown that the $20 \mathrm{kDa} \operatorname{resPrP}^{\mathrm{D}}$ fragment can also be replicated upon inoculation of VV2 SCJD prions (which lack the $20 \mathrm{kDa} \operatorname{resPrP}^{\mathrm{D}}$ component) [16]. This observation suggests that the $20 \mathrm{kDa}$ resPrP ${ }^{\mathrm{D}}$ component in the $\mathrm{MV} 2 \mathrm{~K}$ subtype does not result from a direct templated conversion of $129 \mathrm{M}$ $\operatorname{PrP}^{\mathrm{C}}$ but is rather due to the adaptation of the VV2 $19 \mathrm{kDa}$ strain to the presence of the $129 \mathrm{M}$ allele. Our sequencing efforts have identified residues G82 and G86 as $\mathrm{N}$-termini of the $20 \mathrm{kDa} \operatorname{resPrP}^{\mathrm{D}}$ component. This is consistent with the two most $\mathrm{N}$-terminal residues that we observed in MV2 cases in a previous systematic sequencing study of different sCJD subtypes [29]. These two N-termini of the $20 \mathrm{kDa}$ resPrP ${ }^{\mathrm{D}}$ component differ from those previously identified (as residues G78 and G82) in typical type 1 resPrP $\mathrm{P}^{\mathrm{D}}$ associated with the MM1 phenotype [29]. Furthermore, our conformational stability data surprisingly indicate that, despite the immunoreactivity properties and $\mathrm{N}$-terminus characteristics consistent with $\operatorname{resPrP}^{\mathrm{D}}$ type 1 , the $20 \mathrm{kDa} \operatorname{resPrP}^{\mathrm{D}}$ species in the MV2K subtype appears to have conformational features of resPrP $\mathrm{P}^{\mathrm{D}}$ type 2 , which significantly differ from those of all type 1 subtypes. Finally, a body of evidence indicates that the $20 \mathrm{kDa}$ component of resPrP $\mathrm{P}^{\mathrm{D}}$ is the determinant of kuru plaque formation $[6,16]$ and [Cali et al. unpublished data]. Altogether, 
these features define $\operatorname{PrP}^{\mathrm{D}}$ associated with the MV2K subtype as a unique prion strain in SCJD.

Based on the widely accepted notion that the MV1 variant is indistinguishable from the MM1 subtype, both with regard to the histotype as well as $\operatorname{PrP}^{\mathrm{D}}$ and transmission characteristics, we expected the former variant to show higher proportion of $\operatorname{resPr} \mathrm{P}^{\mathrm{D}}-129 \mathrm{M}$ than resPrP $\mathrm{D}^{\mathrm{D}}-129 \mathrm{~V}$, as is the case for the $\mathrm{MV} 2 \mathrm{C}$ variant. The finding of equal representation of the $129 \mathrm{M}$ and $129 \mathrm{~V}$ allotypes in the MV1 variant raises questions as to the role of these two components in histotype determination. One plausible scenario would require $\operatorname{PrP}^{\mathrm{C}}-129 \mathrm{~V}$ to be converted into $\operatorname{Pr}^{\mathrm{D}}$ with structural characteristics of $\operatorname{PrP}^{\mathrm{D}}-129 \mathrm{M}$ type 1 , participating in determination of the same histotype. Should this be the case, MV1 PrP ${ }^{\mathrm{D}}$ would be the first example of human prion strain which, despite being comprised of similar amounts of two different resPrP $^{\mathrm{D}}$ allotypes, is associated with a homogeneous histotype.

Finally, it must be noted that our findings are at odds with the previous study of Moore and coworkers [20], who examined a similar case population using a similar mass spectrometry-based approach and found no systematic phenotype-specific differences between the populations of two resPrP ${ }^{\mathrm{D}}$ isoforms. This is likely related to less stringent criteria used in the previous study for case selection, which could have resulted in the disproportionate representation of mixed (rather than pure) cases. Indeed, 10 out of the 14 sCJDMV cases examined in the previous study were mixed cases, either MV1-2C/K (4 out of 5 cases) or MV2K-C (6 out of 8 cases). Thus, it seems not surprising that the examination of a population of such mixed cases would lead to inconclusive results. However, when one considers only the "pure" cases used by Moore and colleagues, the relative proportions of the two resPrP $\mathrm{P}^{\mathrm{D}}$ isoforms appear to be comparable to those determined in the present work. Furthermore, all but one (possibly atypical or mixed) of the MV2K iatrogenic CJD cases classified in the study of Moore et al. as "pure" show the predominance of resPrP $\mathrm{P}^{\mathrm{D}} 129 \mathrm{~V}$ over $129 \mathrm{M}$. Therefore, applying more stringent case selection criteria, the findings by Moore et al. are consistent with ours.

\section{Conclusion}

The mass spectrometry-based analysis of relative populations of $\operatorname{resPrP}{ }^{\mathrm{D}}-129 \mathrm{M}$ and $-129 \mathrm{~V}$ allotype in extensively characterized cases of $\mathrm{MV} 2 \mathrm{C}$ and $\mathrm{MV} 2 \mathrm{~K}$ variants, as well as cases of MV1, revealed a novel mechanism for phenotypic determination of human prion diseases. According to this mechanism, in $\mathrm{MV} 2 \mathrm{C}, \operatorname{PrP}^{\mathrm{C}}-129 \mathrm{M}$ is preferentially converted to the disease-associated form, resulting in the predominance of $\operatorname{resPr}^{\mathrm{D}}-129 \mathrm{M}$ over resPrP $\mathrm{P}^{\mathrm{D}}-129 \mathrm{~V}$ and leading to a relatively pure, MM2like histotype. By contrast, in SCJDMV2K, there is a predominance of resPrP $\mathrm{P}^{\mathrm{D}-} 129 \mathrm{~V}$, which has characteristics of type 2 and resembles $\operatorname{res} \operatorname{PrP}^{\mathrm{D}}$ associated with the VV2 subtype. $\operatorname{ResPrP}{ }^{\mathrm{D}}-129 \mathrm{M}$ in the $\mathrm{MV} 2 \mathrm{~K}$ variant is represented by a $20 \mathrm{kDa}$ species, which likely results from the adaptation of the VV2 strain. Furthermore, also in the MV2K-C mixed variants, resPrP $^{\mathrm{D}} 129$ allotypic proportions appear to correlate with the representations of the two histotypes. Finally, in the sCJDMV1 subtype that shares the histotype with the codon 129 homozygous MM1 subtype, $\operatorname{resPrP} \mathrm{P}^{\mathrm{D}}-129 \mathrm{M}$ and $-129 \mathrm{~V}$ were represented in approximately equal proportions.

\section{Supplementary information}

Supplementary information accompanies this paper at https://doi.org/10. 1186/s40478-020-00966-x.

\section{Additional file 1: Table S1. Summary of conformational stability and} PK resistance indices for individual subtypes and variants.

Additional File 2: Table S2. Peptides identified by mass spectrometry in tryptic digests of resPrPD purified from SCJD MM2 and SCJD W2 cases.

Additional File 3: Figure S1. Immunoblots of individual SCJD subtypes used to generate CSI and PK titration indexes. $a$ and b: CSI and PK titration, respectively. Total PrP treated as indicated were quantified by infrared imaging of the electrophoretic band corresponding the unglycosylated isoforms; arrows: upper and lower arrows point to the unglycosylated $20 \mathrm{kDa}$ and $19 \mathrm{kDa}$ components of the MV2Kelectrophoretic profile; single solid and dashed arrows identify the unglycosylated isoforms of resPrP ${ }^{D}$ types 2 and 1, respectively, of indicated SCJD variants and subtypes. Ab 3F4.

Additional File 4: Figure S2. Calibration of the mass spectrometric method for determination of relative concentrations of $129 \mathrm{M}$ and $129 \mathrm{~V}$ PrP in mixtures containing different proportions of both proteins. a: Calibration data for recombinant human PrP (rhuPrP) using five different mixtures of $129 \mathrm{M}$ and $129 \mathrm{~V}$ rhuPrP with concentrations of each protein determined by absorbance at $280 \mathrm{~nm}$. b: Calibration data for resPrPD purified from pure cases of sCJDMM2 and SCJDW2 using five different proportions of $129 \mathrm{M}$ and $129 \mathrm{~V}$ resPrP ${ }^{\mathrm{D}}$ with concentrations of each protein determined by densitometric analysis of Western blots. In each case, the mixtures were digested with trypsin and analyzed by mass spectrometry. Spectral counting method was used to determine the relative proportions of $129 \mathrm{M}$ and $129 \mathrm{~V}$ PrP polymorphs.

Additional File 5: Figure S3. Mass spectrometry data from the individual cases examined. The resPrP $129 \mathrm{M}$ percentages for each of the 3 "pure" cases were: MV2C: 90.3, 88.9, 69.2; MV2K: 31.9, 26.7, 9.3; MV1: $45.2,51,47.9$. The M:V proportions of the two MV2K-C mixed cases are reported in the legend of Fig. 4.

\section{Abbreviations}

Ab: Antibody; CSI: Conformational stability immunoassay; CC: Cerebral cortex; $\mathrm{CbC}$ : Cerebellar cortex; hr: Hour; MM: Homozygous methionine; min: Minutes; MS: Mass spectrometry; MV: Heterozygous methionine/valine; PK: Proteinase K; PrPD: Disease-related prion protein; sCJD: Sporadic Creutzfeldt-Jakob disease; sFI: Sporadic fatal insomnia; W: Homozygous valine

\section{Acknowledgements}

We greatly appreciate the skillful histological preparations by Ms. Diane Kofskey and the invaluable cooperation of all the personnel of the National Prion Disease Pathology Surveillance Center.

\section{Authors' contributions}

SKN, XX, IC, SN, WKS, and PG were responsible for concept and design of the project. SKN, XX, IC, LC, PGF, MN, JL, BS, BA, SN, VLS, WKS, PG were responsible for data analysis and interpretation. SKN, XX, IC, WKS and PG were responsible for writing the manuscript and drafting the Figures. The authors read and approved the final manuscript. 


\section{Funding}

This study was supported by the US National Institutes of Health Grants P01 Al106705, R01 NS083687 (to W.K.S. and P.G.), R01 GM061797 (to W.K.S.), P01 Al077774 and The Charles S. Britton Fund (to P.G.), CDC UR8/CCU515004 (to B.S.A.) and Alberta Prion Research Institute Explorations grant 201700014 (to V.L.S.).

\section{Availability of data and materials}

The datasets used in the current study are available from the corresponding author on reasonable request.

\section{Ethics approval and consent to participate}

The human brain tissues used in the current study were provided by NPDPSC. All the procedures were performed with institutional review board of University Hospitals Cleveland Medical Center (\#5-14-09) approval and as per regulations of 1964 Declaration of Helsinki.

\section{Consent for publication}

\section{Not applicable.}

\section{Competing interests}

All the authors have read and approved the manuscript and the authors declare that they have no conflicts of interest.

\section{Author details}

'Department of Pathology, Case Western Reserve University, School of Medicine, Cleveland, OH 44106, USA. ²Department of Physiology and Biophysics, Case Western Reserve University, School of Medicine, Cleveland, $\mathrm{OH} 44106$, USA. ${ }^{3}$ National Prion Disease Pathology Surveillance Center, Case Western Reserve University, School of Medicine, Cleveland, OH 44106, USA. ${ }^{4}$ Department of Advanced Medical and Surgical Sciences, University of Campania "L. Vanvitelli", 81100 Caserta, Italy. ${ }^{5}$ Department of Mental Health and Emergency Psychiatry, P. O. "Maresca", Asl Napoli 3 Sud, 80059 Torre del Greco, Italy. Vascular Medicine Institute, University of Pittsburgh, Pittsburgh, PA 15261, USA. ${ }^{7}$ Department of Neurology, Case Western Reserve University, School of Medicine, Cleveland, OH 44106, USA. ${ }^{8}$ Department of Psychiatry, Case Western Reserve University, Cleveland, OH 44106, USA. ${ }^{9}$ Centre for Prions and Protein Folding Diseases, University of Alberta, Edmonton T6G2M8, Canada.

Received: 9 June 2020 Accepted: 11 June 2020

\section{Published online: 19 June 2020}

\section{References}

1. Baiardi S, Rossi M, Capellari S, Parchi P (2019) Recent advances in the histomolecular pathology of human prion disease. Brain Pathol 29:278-300

2. Bantscheff M, Lemeer S, Savitski MM, Kuster B (2012) Quantitative mass spectrometry in proteomics: critical review update from 2007 to the present. Anal Bioanal Chem 404:939-965

3. Bishop MT, Will RG, Manson JC (2010) Defining sporadic Creutzfeldt-Jakob disease strains and their transmission properties. Proc Natl Acad Sci U S A 107:12005-12010. https://doi.org/10.1073/pnas.1004688107

4. Cali I, Castellani R, Alshekhlee A, Cohen Y, Blevins J, Yuan J, Langeveld JPM, Parchi P, Safar JG, Zou W-Q, Gambetti P (2009) Co-existence of scrapie prion protein types 1 and 2 in sporadic Creutzfeldt-Jakob disease: its effect on the phenotype and prion-type characteristics. Brain 132:2643-2658. https://doi. org/10.1093/brain/awp196

5. Cali I, Castellani R, Yuan J, Al-Shekhlee A, Cohen ML, Xiao X, Moleres FJ, Parchi P, Zou W-Q, Gambetti P (2006) Classification of sporadic CreutzfeldtJakob disease revisited. Brain 129:2266-2277. https://doi.org/10.1093/brain/ awl224

6. Cali I, Cohen ML, Haik S, Parchi P, Giaccone G, Collins SJ, Kofskey D, Wang H, McLean CA, Brandel JP, Privat N, Sazdovitch V, Duyckaerts C, Kitamoto T, Belay ED, Maddox RA, Tagliavini F, Pocchiari M, Leschek E, Appleby BS, Safar JG, Schonberger LB, Gambetti P (2018) latrogenic Creutzfeldt-Jakob disease with amyloid- $\beta$ pathology: an international study. Acta Neuropathol Commun 6:5. https://doi.org/10.1186/s40478-017-0503-z

7. Cali I, Puoti G, Smucny J, Curtiss PM, Cracco L, Kitamoto T, Occhipinti R, Cohen ML, Appleby BS, Gambetti P (2020) Co-existence of PrPD types 1 and 2 in sporadic Creutzfeldt-Jakob disease of the W subgroup: phenotypic and prion protein characteristics. Sci Rep 10:1503. https://doi.org/10.1038/ s41598-020-58446-0

8. Cracco L, Appleby BS, Gambetti P (2018) Fatal familial insomnia and sporadic fatal insomnia. Handb Clin Neurol 153:271-299. https://doi.org/10. 1016/B978-0-444-63945-5.00015-5

9. Cracco L, Notari S, Cali I, Sy M-S, Chen SG, Cohen ML, Ghetti B, Appleby BS, Zou W-Q, Caughey B, Safar JG, Gambetti P (2017) Novel strain properties distinguishing sporadic prion diseases sharing prion protein genotype and prion type. Sci Rep 7:38280. https://doi.org/10.1038/srep38280

10. Cracco L, Xiao X, Nemani SK, Lavrich J, Cali I, Ghetti B, Notari S, Surewicz WK, Gambetti P (2019) Gerstmann-Sträussler-Scheinker disease revisited: accumulation of covalently-linked multimers of internal prion protein fragments. Acta Neuropathol Commun 7:1. https://doi.org/10.1186/s40478019-0734-2

11. Féraudet C, Morel N, Simon S, Volland H, Frobert $Y$, Créminon C, Vilette D, Lehmann S, Grassi J (2005) Screening of 145 anti-PrP monoclonal antibodies for their capacity to inhibit PrPSc replication in infected cells. J Biol Chem 280:11247-11258. https://doi.org/10.1074/jbc.M407006200

12. Gambetti $P$, Kong Q, Zou W, Parchi P, Chen SG (2003) Sporadic and familial CJD: classification and characterisation. Br Med Bull 66:213-239. https://doi. org/10.1093/bmb/66.1.213

13. Ghaemmaghami S, Russo M, Renslo AR (2014) Successes and challenges in phenotype-based lead discovery for prion diseases. J Med Chem 57:69196929. https://doi.org/10.1021/jm5001425

14. Gielbert A, Thorne JK, Hope J (2015) Pyroglutamyl-N-terminal prion protein fragments in sheep brain following the development of transmissible spongiform encephalopathies. Front Mol Biosci 2:7. https://doi.org/10.3389/ fmolb.2015.00007

15. Kascsak RJ, Rubenstein R, Merz PA, Tonna-DeMasi M, Fersko R, Carp RI, Wisniewski HM, Diringer H (1987) Mouse polyclonal and monoclonal antibody to scrapie-associated fibril proteins. J Virol 61:3688-3693. https:// doi.org/10.1128/jvi.61.12.3688-3693.1987

16. Kobayashi A, Iwasaki Y, Otsuka H, Yamada M, Yoshida M, Matsuura Y, Mohri S, Kitamoto T (2013) Deciphering the pathogenesis of sporadic CreutzfeldtJakob disease with codon $129 \mathrm{M}$ N and type 2 abnormal prion protein. Acta Neuropathol Commun 1:74. https://doi.org/10.1186/2051-5960-1-74

17. Kobayashi A, Sakuma N, Matsuura Y, Mohri S, Aguzzi A, Kitamoto T (2010) Experimental verification of a traceback phenomenon in prion infection. J Virol 84:3230-3238. https://doi.org/10.1128/JVI.02387-09

18. Langeveld JPM, Jacobs JG, Erkens JHF, Bossers A, Van Zijderveld FG, Van Keulen LJM (2006) Rapid and discriminatory diagnosis of scrapie and BSE in retro-pharyngeal lymph nodes of sheep. BMC Vet Res 2. https://doi.org/10. 1186/1746-6148-2-19

19. Moda F, Suardi S, Di Fede G, Indaco A, Limido L, Vimercati C, Ruggerone M, Campagnani I, Langeveld J, Terruzzi A, Brambilla A, Zerbi P, Fociani P, Bishop MT, Will RG, Manson JC, Giaccone G, Tagliavini F (2012) MM2thalamic Creutzfeldt-Jakob disease: Neuropathological, biochemical and transmission studies identify a distinctive prion strain. Brain Pathol 22:662669. https://doi.org/10.1111/j.1750-3639.2012.00572.x

20. Moore RA, Head MW, Ironside JW, Ritchie DL, Zanusso G, Pyo Choi Y, Priola SA (2016) The distribution of prion protein Allotypes differs between sporadic and iatrogenic Creutzfeldt-Jakob disease patients. PLoS Pathog 12: e1005416. https://doi.org/10.1371/journal.ppat.1005416

21. Morillas M, Swietnicki W, Gambetti P, Surewicz WK (1999) Membrane environment alters the conformational structure of the recombinant human prion protein. J Biol Chem 274:36859-36865. https://doi.org/10.1074/jbc.274.52.36859

22. Notari S, Capellari S, Giese A, Westner I, Baruzzi A, Ghetti B, Gambetti P, Kretzschmar HA, Parchi P (2004) Effects of different experimental conditions on the PrPSC core generated by protease digestion: implications for strain typing and molecular classification of CJD. J Biol Chem 279:16797-16804. https://doi.org/10.1074/jbc.M313220200

23. Parchi $P$, De Boni L, Saverioni D, Cohen ML, Ferrer I, Gambetti P, Gelpi E, Giaccone G, Hauw JJ, Höftberger R, Ironside JW, Jansen C, Kovacs GG, Rozemuller A, Seilhean D, Tagliavini F, Giese A, Kretzschmar HA (2012) Consensus classification of human prion disease histotypes allows reliable identification of molecular subtypes: an inter-rater study among surveillance centres in Europe and USA. Acta Neuropathol 124:517-529. https://doi.org/ 10.1007/s00401-012-1002-8

24. Parchi P, Capellari S, Chen SG, Petersen RB, Gambetti P, Kopp N, Brown P, Kitamoto T, Tateishi J, Giese A, Kretzschmar H, Collinge J, Hill AF, Sidle KCL, Ironside J (1997) Typing prion isoforms. Nature 386:232-234 
25. Parchi P, Castellani R, Capellari S, Ghetti B, Young K, Chen SG, Farlow M, Dickson DW, Sima AAF, Trojanowski JQ, Petersen RB, Gambetti P (1996) Molecular basis of phenotypic variability in sporadic Creutzfeldt-Jakob disease. Ann Neurol 39:767-778. https://doi.org/10.1002/ana.410390613

26. Parchi P, Cescatti M, Notari S, Schulz-Schaeffer WJ, Capellari S, Giese A, Zou W-Q, Kretzschmar H, Ghetti B, Brown P (2010) Agent strain variation in human prion disease: insights from a molecular and pathological review of the National Institutes of Health series of experimentally transmitted disease. Brain 133:3030-3042. https://doi.org/10.1093/brain/awq234

27. Parchi P, Giese A, Capellari S, Brown P, Schulz-Schaeffer W, Windl O, Zerr I, Budka H, Kopp N, Piccardo P, Poser S, Rojiani A, Streichemberger N, Julien J, Vital C, Ghetti B, Gambetti P, Kretzschmar H (1999) Classification of sporadic Creutzfeldt-Jakob disease based on molecular and phenotypic analysis of 300 subjects. Ann Neurol 46:224-233. https://doi.org/10.1002/15318249(199908)46:2<224:AID-ANA12>3.0.CO:2-W

28. Parchi P, Strammiello R, Giese A, Kretzschmar H (2011) Phenotypic variability of sporadic human prion disease and its molecular basis: past, present, and future. Acta Neuropathol 121:91-112

29. Parchi P, Zou W, Wang W, Brown P, Capellari S, Ghetti B, Kopp N, SchulzSchaeffer WJ, Kretzschmar HA, Head MW, Ironside JW, Gambetti P, Chen SG (2000) Genetic influence on the structural variations of the abnormal prion protein. Proc Natl Acad Sci U S A 97:10168-10172. https://doi.org/10.1073/ pnas. 97.18 .10168

30. Pastore M, Chin SS, Bell KL, Dong Z, Yang Q, Yang L, Yuan J, Chen SG, Gambetti P, Zou WQ (2005) Creutzfeldt-Jakob disease (CJD) with a mutation at codon 148 of prion protein gene: relationship with sporadic CJD. Am J Pathol 167:1729-1738. https://doi.org/10.1016/S0002-9440(10)61254-0

31. Safar JG, Xiao X, Kabir ME, Chen S, Kim C, Haldiman T, Cohen Y, Chen W, Cohen ML, Surewicz WK (2015) Structural determinants of phenotypic diversity and replication rate of human prions. PLoS Pathog 11:e1004832. https://doi.org/10.1371/journal.ppat.1004832

32. Yull HM, Ritchie DL, Langeveld JPM, van Zijderveld FG, Bruce ME, Ironside JW, Head MW (2006) Detection of type 1 prion protein in variant Creutzfeldt-Jakob disease. Am J Pathol 168:151-157. https://doi.org/10.2353/ ajpath. 2006.050766

33. Zahn R, Von Schroetter C, Wüthrich K (1997) Human prion proteins expressed in Escherichia cell and purified by high-affinity column refolding. FEBS Lett 417:400-404. https://doi.org/10.1016/S0014-5793(97)01330-6

34. Zerr I, Parchi P. Sporadic Creutzfeldt-Jakob disease. Handb Clin Neurol. 2018; 153:155-74. https://doi.org/10.1016/B978-0-444-63945-5.00009-X.

35. Zou WQ, Zheng J, Gray DM, Gambetti P, Chen SG (2004) Antibody to DNA detects scrapie but not normal prion protein. Proc Natl Acad Sci U S A 101: 1380-1385. https://doi.org/10.1073/pnas.0307825100

\section{Publisher's Note}

Springer Nature remains neutral with regard to jurisdictional claims in published maps and institutional affiliations.

Ready to submit your research? Choose BMC and benefit from:

- fast, convenient online submission

- thorough peer review by experienced researchers in your field

- rapid publication on acceptance

- support for research data, including large and complex data types

- gold Open Access which fosters wider collaboration and increased citations

- maximum visibility for your research: over $100 \mathrm{M}$ website views per year

At $\mathrm{BMC}$, research is always in progress.

Learn more biomedcentral.com/submissions 